\title{
Preserving the Rural Place: A Geotourism in a Globalized World
}

\author{
Anthony Ikhide Osawe \\ Department of Geography and Environmental Management, Ambrose Alli University, \\ Ekpoma, Edo State Nigeria
}

\begin{abstract}
The traditional rural place signifies rural areas with small settlements, low population density, agrarian-based economies and a traditional society. This paper aimed at drawing the attention of the policy maker's attention to the importance and need to create values from rural landscape and preserve the existing biodiversity of the local environment. People do first occupy a space that are transformed into a meaningful place or given a sense of place vital for navigating something like an abstract geometric space. Often time, this captures our live experience of the landscape. The global socio-ecological took roots from moral crisis emerging from unsustainable consumption and a new paradigm of sustainable development directed at holistic human development. As more than half of the Nigeria's rural population live below poverty line speaks volumes that much needs to be done. Policies on ecosystem services need review for adequate protection for sustainable service delivery. Above all, provide opportunity for all to have synergies that promote the development of rural organization such as community-driven cooperative to enhance investment in essential infrastructures and services, and recognize the role of urban areas in fostering rural development.
\end{abstract}

Keywords: Rural areas, Geo-tourism, Place, empowerment, Sustainable rural development

DOI: $10.7176 / \mathrm{JTHS} / 56-02$

Publication date:May $31^{\text {st }} 2021$

\section{Introduction}

These days, in many advanced and developing societies, rural communities are in crisis. Tourism in rural areas has been one of the major policy options in advanced societies such as in Western Europe and Japan for sustaining rural economies and agriculture while conserving their authentic rural landscapes and cultures. Ostensibly, this is considered as an approach to "sustainable rural development" a worldwide concept through the use of local resource endowments including landscapes and cultural traditions. Since the 2000s, there are copious professional literatures enthusiastic to guidelines or best practices in managing heritage sites, both taken from the list of UNESCO World Heritage Sites (WHS) and listed by the IUCN, the most relevant organizations as international leaders in natural heritage management. Geo-tourism aims to sustain and enhance the nature of the places its people call home and to sustain the quality of life for this and future generations."But the critical concept of "preserving the rural place" is left undefined. Clarifying what we mean by preserving the place will help rural areas grow in ways that protect their very environment while enhancing the economic well-being of its people and the places they call home through appropriate management, tourism sustainable development or good governance.There is the side that rural communities and people are only able to preserve their physical environment through the endless commodification of landscapes development could be a phenomenon that is effective only within this world view. But these circumstances view from the traditional core-periphery theory, the unstable situation they face may be seen as that of hovering on difficult times, on one side, is the progressive depopulation and economic decline, and on the other side unchecked, powerful and in many ways destructive capitalist development patterns. Markusen (1985) observed that of uneven development theory, such a differentiation of rural areas may be seen as part of a more complex and uneven process of regional restructuring that is a spatial expression of intent of profit maximization behaviour of the capitalist production system. However, this geographical dynamism under the capitalist economic system may lead to urban/suburban sprawl, that converts ever more remote rural regions, and bringing with it environmental degradation and social problems (Kitano, 2010). In the midst of the outlined circumstance, there have been some rural communities that succeeded through the promotion of tourism in sustaining the scenery, culture, and economy of their area. $\mathrm{Be}$ that as it may, it is erroneous to think that through commodification any rural community can indefinitely protect its identity as a rural community. Kitano (2010) noted that reason for this lies in the inability to avoid the competition that exists in the rural tourism market once commodification has taken place. In order to sustain a position as a saleable commodity or popular destination, various factors must be considered. These include not only obvious factors such as quality of landscapes and cultural attractions (genuineness), but also location, marketing, advertising, distance between competing destinations, and the broadly consciousness and capacity of the local government and community. The main assumption is that despite the wide international distribution and the great intellectual and practical needs for this system, local heritage management is essentially based on the specific territorial and local context, so that local management is relatively independent of the effort towards global standardization. 
This paper is situated within the extant theoretical framework of rural tourism. It will also highlight the importance of reimagining the rural environment and resources: re-imagination is often central to seeing rurality as a valuable asset with entrepreneurial opportunities rather than as unwanted backwardness. It will also establish a framework for understanding and identifying the common and uncommon attributes that make up 'the rural place'. It can help contribute to a potential framework to help local residents take stock of their communities and take part in improving them. Practical insights are offered to tourism marketers, community leaders, and policy-makers on how 'preserving the rural place' is constructed and ultimately how it can be sustained and enhanced.

\section{Literature Review}

This literature review adopted the conceptual framework of geo-tourism, which is an emerging approach to tourism that has a focus on enhancing the geographical nature of a place. The history and evolution of geotourism is explored, and how geo-tourism differs from ecotourism and where geo-tourism is now heading, particularly in rural areas are documented. Then the concepts of 'place' and 'space' are examined in order to clarify their various meanings in context and analyze their linkage.

\section{Introduction to Geo-tourism}

The creation of term geo-tourism drew on many influential ideas in the field of sustainable tourism, Particularly the Brundtland Report, which introduced the concept of sustainable development in 1987; that defines sustainable development as "development that meets the needs of the present without compromising the ability of future generations to meet their own needs" (WCED 1987). In 1997, the National Geographic started advancing the concept of geo-tourism (Boley, Nickerson, \& Bosak 2011), and in 2003 the term made its formal debut at the Travel Industry Association in partnership with the National Geographic Society, when Jonathan Tourtellot of National Geographic Traveler firstly defined geo-tourism as, "tourism that sustains or enhances the geographical character of a place -its environment, heritage, aesthetics, culture, and the well-being of its residents" (Stokes, Cook, \& Drew 2003). Geo-tourism has emerged not as a niche form of tourism that focuses on sustaining one specific dimension of the travel experience, but rather as a unique approach to maintaining the character of place (Boley et al. 2011).

In the evolution of the tourism industry, its related literature has spurred various tourism models starting from mass tourism through sustainable tourism to ecotourism and now geotourism.

Boley et al. (2011) note that tourism literature features diverse efforts to define sustainable tourism and ecotourism, and it reveals a problematic lack of unity. This has led to the manifold expansion and fragmentation of "sustainable tourism" to include ecotourism (Ceballos-Lascuráin 1996); geotourism (Stokes, et al. 2003); new tourism (Rosenow and Pulsipher 1979); ethnic tourism (Moscardo and Pearce 1999); pro-poor tourism (Ashley and Roe 2002); alternative tourism (Butler 1990); justice tourism (Scheyvens 2002); and volunteer tourism (Wearing 2001). "Ecotourism," in the intervening time, has also been beleaguered with a lack of a consistent definition or understanding. In 2001, a content analysis of 85 definitions of ecotourism found that $45 \%$ limited ecotourism to activity within protected areas, $50 \%$ made no reference to culture, and only $48 \%$ included benefiting local residents (Fennel 2001; Tipton, 2017). In fact, little agreement has emerged in defining what constitutes ecotourism, with substantial distinctions made between ecotourism and geo-tourism in at least $50 \%$ of the definitions (Boley et al. 2011; Tipton, 2017).

Today geo-tourism has emerged as a uniquely holistic approach focused on sustaining the uniqueness of a region. Geo-tourism differs from ecotourism by encompassing the entire working landscape as part of the tourist attraction. It is not limited to protected or pristine areas, and it seeks to enable local residents to shape tourism in their midst (Stokes et al. 2003; Boley et al. 2011; Tipton, 2017).

While sustainable tourism has been depicted as a vague concept at best, because it is oriented to a future that never arrives, geo-tourism promises more tangible outcomes centered on changing tourists' expectations through a community-first focus rather than forcing a destination to adapt to the demands of tourism (Boley et al. 2011; Tipton, 2017). Given geo-tourism's aim to sustain the region's character through preserving local values and assets, using a participatory approach as a method to identify attributes that make up the nature of place will enable more informed decision-making in tourism management, marketing, and development going forward. Since many of these local "social landscapes" have natural resources at their core, those tasked with tourism development can make the most of a tremendous opportunity to add community character to traditional metrics such as nonresident satisfaction and ecological quality (Amsden, Stedman, and Kruger 2010).

\subsection{Planning, heritage and local geopolitical conflict}

Planning, heritage and local geopolitical conflicts changing land uses and planning process are frequently sources of conflicts. Even better, Cullingworth and Nadin (2006, p.2) explain that "politics, conflicts and dispute are at the centre of land use planning. Conflict arises because of the competing demands for the use of land, 
because of the externality effects that arise when the use of land changes, and because of the uneven distribution of costs and benefits which results from development. If there were no conflicts, there would be no need for planning. Indeed, planning might usefully be defined as the process by which government resolves disputes about land uses" (Bailoni, 2016). Indeed, while the first protests against planning schemes arise from the 1950s, they increase from the 1970's to become systematic and symptomatic of any sizeable project (Dziedzicki, 2003; Bailoni, 2013), such as power plants (nuclear, dam, wind farm, etc.), transport links (road, railway, airport, etc.), any other public service infrastructures, urban sprawl effects, urban renewal schemes, etc.

Subra (2007) observes that the protest is thus becoming common and widespread. These planning conflicts are stakeholders' connections and interactions which confront divergent ambitions, contradictory perceptions and personal or mutual interests of those concerned. The opposition arises from local concerns and interests, which can cause NIMBY ("Not In My Back Yard") reactions, as well as global views, which can cause NIABY ("Not In Anybody's Back Yard") reactions.

The protesters are usually neighbouring residents, environmental activists, citizens, local politicians, local history, cultural or heritage societies, economic stakeholders, lobbyists or corporations (Wolsink, 1994; Dziedzicki, 2003). However, they mobilised having a shared and common arguments, whatever may be their motivations or their side view.

Thus these planning conflicts or land- use conflicts, or environmental conflicts are geopolitical disputes, in which arguments are constructed by using perceptions of singularity and potential development of territories, environment and landscapes (Bailoni, 2016). These feelings of uniqueness arise often from heritage elements, and contribute to defining a local identity, an "Identity cement" (Gravari-Barbas \& Veschambre, 2003).So, the protesters against a planning scheme aim to preserve the environment, to avoid nuisance and pollution, to protect an iconic heritage or landscape, but also to defend a part of local identity (Bailoni, 2013).

\subsection{Spatial Distribution and Sustainable Development of Tourism}

Studies on the relationships between rational spatial layout and sustainable ecological development (Hall, 1998; Wang, et al., 2006) were influenced by Howard's garden city theory (Howard, 1965) which was an excellent exploration into "the peaceful path to real reform" through urban planning. Farrell, et al., (2004) was one of the foremost researchers in sustainable tourism development and considered tourism destinations as complex and dynamic social-ecological systems. Lobley \& Potter, (2004) used terms such as resilience and adaptive management to explain issues such as the impacts of tourism, while Nelson (2001) responded to crises of climate change, disaster, etc. and the sustainable utilization of resources (Kiss, 2000). In studies related to environmental attitude, humanistic geographers provided clear responses to social problems (Tuan, 2001) and explored the impacts of the economy, lifestyles and physical environments on environmental values from multiple perspectives (i.e., space, place and individual experience- (Daly, 2015; Carter et al., 2013).

In recent past, Chinese scholars have studied sustainable tourism biased on tourism space change (Wang, et al., 2010), ecological security of tourism destinations (Sigala, 2008), environmental carrying capacity (Brown, et al., 1997), and Shaker's (2018) community participation in tourism development, and sustainable development models. In addition, the studies have mostly focused on large and medium-scale areas. Scholars have attached great importance to the selection of spatial location and spatial layout in tourism destinations (Tosun, 2006). With the escalating ecological problems caused by spatial disorder, scholars have expanded their research into sustainable tourism, mainly from the perspectives of tourism evolution processes, tourism environmental carrying capacity, community participation, sustainable development models, etc. From the 1970s, Chinese scholars have made advancements on the relationships between spatial layout and environmental protection, based on Butler et al.'s (1991) recreation opportunity spectrum (ROS) theory and Gunn's (1998) community attraction complex model, that have been internationally recognized and identified as examples of small-scale tourism spatial layouts. For instance, the China's ecotourism opportunity spectrum (CECOS), Ahn, et.al., (2002) LAC- limits of acceptable change, and Tao, et al. (2017) VERP-visitor experience and resources protection have become important bases for small-scale tourism space management (Huang, et al., 2006) which safeguards the sustainable rights to scarce resources and strengthens the enclosure and visibility of spatial boundary networks, and in this manner, it has been regarded as the most powerful law for maintaining internal affairs.

2.3 The Villages in the Urban World: The nature of cities and villages in any historical period, urban-rural relations are indispensable feature of human society, and one of the primary aspects of historically defined urban-rural relations are the social relations of production. Although this fundamental point may not be obvious, it is the basic force that shapes the visible social, economic, environmental, and/or political phenomena in rural areas today. Taking a conceptual perspective in which 'rural' simply represents 'agrarian' or agricultural societies, and 'urban' principally represents 'industrial' societies, is not an appropriate way to observe and discuss current rural development problems. In fact, today, as a result of the growth and spread of small and medium industries, and improved transportation in rural areas, rural populations have largely become a wage 
labour proletariat in non-agricultural employment.

Urban-rural relations in different theoretical traditions, are generally speaking, one of the most popular and influential concepts for distinguishing the quality of being rural from that of being urban. Max Weber's classical urban-rural dichotomy distinguishes cities and villages based on such criteria as dominant industrial/occupational types, residential patterns, communal kinship, and political/administrative forms (Weber 1958). In the 1920s, the rural sociologists Sorokin and Zimmerman attempted to build on Weber's distinction by adding new social, economic, environmental, and demographic criteria to their typologies of "Urban World" and "Rural World" (1929).

\section{Preserving Ruralities in Rural /urban continuum \\ 3.1 Urban and Rural}

The urban sociologists in the Chicago School with their concept of 'urbanism' in which typical urban life styles are assumed to expand to suburbs and rural regions in an unchecked manner (Wirth 1938; Fischer 1984). Their definition reflects urban/industrial societies and rural/folk societies which assume an urban-rural continuum in which cities and villages are socio-culturally continuous and their differentiation takes place according to the degree of acceptance of their acceptance of "urban" social, human ecological, and social psychological characteristics (Takahashi 1988). These arguments on urbanism lack a serious consideration of the social relations of production as an essential dynamic of the capitalist society.

Innovative Urban Economic theorists, including geographers and urban sociologists, are of the view that cities and villages are economically and spatially continuous with respect to capital accumulation and its spatial (or geographical) appearance, but they also differ in critical ways from the Chicago School. Under the capitalist mode of production ever sprawling urbanization, accompanied by geographical accumulation of capital and uneven development of space are driven by the dynamics of capital. Harvey (1985) views the term "urban" as being a continuous basin system with a core and peripheries. His argument is that the distinction between urban and rural is now meaningless with respect to production functions; the distinction is, rather, an expression of the spatial division of consumption. In this sense, regardless of their visible physical landscapes, rural villages are no longer 'rural' in the traditional sense. The scope of the connection of rural areas to the economic core (cities and urban areas) is the precarious element. The relationship (through transportation, technology, and location) determines for rural areas the availability of multiple economic bases and business opportunities.

\subsection{The globalized urban world:}

The prevalent terms global economy and globalization defines the present stage of capitalist development and could be noticed that the first three quarters of the twentieth century were an era of state-driven industrialization followed by widespread urbanization. These forces affected the physical space, as well as people's mentality and way of life. During this process the ultimate objectives of the state and that of industrial capitalists were essentially the same (Kitano, 2010). In the present global economy, there is an ever growing domination of multinational capital in all dimensions of economic activity. Regions and localities, including both cities and villages, are being transformed. Nothing on earth can be isolated from these forces. No one can escape the global economics' influence. Today, rural communities are only allowed to exist within the globalized urban world.

The harmonious co-existence of the rural scene in terms of the cultural heritage, biodiversity with the local environment is of significant importance. The significance of a place embraces all the diverse cultural and natural heritage values that people associate with it, or which prompt them to respond to it. These values tend to grow in strength and complexity over time, as understanding deepens and people's perceptions of a place evolve. Understanding and articulating the values and significance of a place is necessary to inform decisions about its future. The degree of significance determines what, if any, preservation, including statutory designation, is appropriate under law and policy. The rural environment contains an authentic and dynamic record of human activity. It has been determined by people responding to the surroundings they inherit, and exemplifies the aspirations, skills and investment of successive, that allow people to use, enjoy and benefit from it, without compromising the ability of future generations to do the same. Preserving the rural place involves understanding and conserving the heritage values of a place.

\section{Concept of Place and Space:}

With the inconsistency, the uniqueness of a rural place and the lives of people there are peculiarly different from that of an urban place. The peculiarity often links the distinctiveness of rural life and environment with ecological/cultural ideologies based on a site-specific, place-bound perception. Nevertheless, I propose that there must be another way to look at contemporary rural or, more accurately, regional problems in advanced industrialized societies. As I mentioned above, cities and villages are continuous entities, driven to this continuity by the universal social, economic, and spatial dynamics of a world-historical process that takes place regardless of visible differences in demography, cultural values, physical landscapes, and dominant economic 
activities. The underlying concept here is 'space,' not place. Lobao (1996) opines that we must understand that everyone in a region, locality, or community is affected by the past and by the present, and that there is a dualistic nature of any locality 'place' as a particularistic concept and 'space' as a relative one. Thus the issue of commodification through rural tourism could be considered within this framework.

\subsection{Nature of place: Place and Analysis in Geography}

Though a conical Concept in Geography, the meaning and analytic role of place has been unsettled among geographers. In humanistic tradition Tuan (1974) poses place in contrast to space. Space is posited as the realm of action, place is where one stops,

Place is taken as an empirical concept that reflects local identity or genius loci. In rural areas "place" has its origin as "a fragment of agro-pastoral space" (Lefebvre 1991). "Place" is a subjective vernacular entity expressing people's experience and a locality's history. Every locality has its own uniqueness as a place, an identity that has been sustained by an exclusive historical context that include natural environment, architecture, topography, physical distance from the outside, cultural / religious, values, and tribal/communal customs. According to Relph (1993), "A place is a whole phenomenon, consisting of the three intertwined elements of a specific landscape with both built and natural elements, a pattern of social activities that should be adapted to the advantages or virtues of a particular location, and a set of personal and shared meanings."

It is common to have a nostalgic and intimate feeling with respect to one's place which in Africa we call "native place" Which refers to a rural village. The value attached to rural areas as part of a country's cultural heritage is often discussed in this context. Consequently, people often consider place and absolute space as being identical. It is against this background, Gottfried's explanation of rural landscapes as: "People's intense experiences with the land have enhanced the cultural value of rural areas. Most rural landscapes are "constructed" - that is, they show a many-layered history of human intervention. Cultural conservation holds an important place in rural policy because it reinforces the sensory experience of the rural landscape and strengthens landscape's role as a symbol of stability" (Gottfried, 1995). This still does not make 'place' mere remnant of the past, but their "local identities" as cultural expressions of a changing world. Therefore, place can mean 'bounded performance' at a specific historical period. In this setting of place, the urban-rural dichotomy proposed by earlier sociologists is still a useful concept and an effective language for taking into account differences in social and physical elements between urban and rural regions. Yet, while it is common for people to assessment place in a narrow way as a culturally, socially, or sometimes economically bounded territory (Massey 1993: 143), there is another aspect of place in the broader context of political economy to which social scientists must pay serious attention.

\subsection{Preserving the sense of place?}

The "sense of place" as a concept is recognized by UNESCO and ICOMOS, at their core value of heritage places in reference to the geniuses, both guards and expressions of antiquity places. The 2008 Quebec Declaration on "Safeguarding the spirit of place" at the 16th General Assembly and International Scientific Symposium of ICOMOS recalls previous measures (Icomos symposium and 2003 Kimberley Declaration) to recognize the characteristics of "living, social and spiritual" places through the "beliefs, memories, affiliations and expertise" of local communities.

The elusive dimension of heritage is central to the spirit of place definition which "consists of hardware (sites, landscapes, buildings, objects) and intangible (memoirs, oral, written narrative documents, rituals, festivals, traditional knowledge, values, odors) physical and spiritual, that give meaning, value, emotion and mystery to place "(Prats \& Thibault, 2003; McNamara, 2014). These elements are significant and contribute to give a specific spirit to places: "the spirit builds the place and at the same time, the place structures and invests the spirit" (Prats \& Thibault, 2003). This is why the sense of place seems obvious where communities are most likely to grab it and to hand over it to visitors. Heritage sites stakeholders (managers, communities, young people, tourism professionals etc.) are deeply asked by professionals or international organizations to make the sense of place visible to visitors. In France, heritage site management professionals are clearly facing this issue.

Defined as "an atmosphere (...), symbolic images, intended or felt (...), a complex alchemy, (...) fed by literary and artistic references", sense of place is discussed through the tension between preservation and tourism by ICOMOS France (Prats and Thibault, 2003), the Grands Sites de France network (Vour'ch, 1999) and the ministries of Culture and Ecology.

For these experts, sense of place is "the tangible and intangible identity of the place, taken into an evolutionary dimension, which enables to define the carrying capacity and the quality of site management (Prats \& Thibault, 2003). In 1999, the Grands Sites de France professional network organized a special conference devoted to sense of the place (Vour'ch 1999) where heritage stakeholders defined sense of place for their sites: spirit of freedom, of legends or devotion (for the Pointe du Raz), retreat and renewal (for Saint-Guilhem-leDésert), end of the world (for Cirque du fer à cheval)... To explain further, the example of the Mont Saint Michel 
indicates that stakeholders can also put into practice sense of place with huge management project. For instance, over a decade, the Opération Grand Site of Mont Saint-Michel gave back the mount to the sea, requiring the lost island to be in harmony with its sense of place.

The sense of the place is becoming an important part of heritage management. It appears more and more as a way to respect the identity of places, to integrate local reality in the site management, while applying heritage sustainable management

\section{Nature of space:}

Castells (1992) sees 'Space' as both an abstract and an objective concept for describing society. The concept of space has been developed in the tradition of western Marxist theorists based on the work of Lefebvre (Soja 1989). Unlike place, space is a continuous entity — not a bounded territory. Space is best recognized as a contradiction of capital accumulation as capitalism evolves. Capital does not belong to any place; rather it is highly mobile spatially. Uneven regional development is an inevitable consequence of uneven capital accumulation, accompanying socio-spatial differentiation between a core and its peripheries and/or a spatial division of labour. Castells (1977) gives an explicit definition of space:

"Space is a material product, in relation with other material elements - among others, men, who themselves enter into particular social relations, which give to space (and to the other elements of the combination) a form, a function, a social signification. It is not, therefore, a mere occasion for the deployment of the social structure, but a concrete expression of each historical ensemble in which a society is specified."

Lobao (1996) provides a summary of the nature of space:"Global economic change is an uneven process over time and within and between nations. It transforms economic structure. It alters social relations or class structure and other asymmetrical power relations of gender, age, and ethnicity brings about new strategies of state intervention, and affects the levels at which populations are able to reproduce themselves. As a consequence, places are differentiated with regard to production structures, social relations, demographic and other characteristics reflective of local reproduction..."

This was why, Harvey argues that 'urban' is the agglomeration of physical infrastructure and facilities for production, exchange, and consumption, and that it is a necessary means of capital accumulation for reproduction (using his term, 'urban built environment'). This is one material aspect of space and is the appropriation of space (Harvey 1985). In this sense, what we call rural areas (except those rural areas where resource-exploitative, mechanistic, industrial agriculture is operated) in terms of landscape is increasingly a spatial periphery of the global capitalist system. Hence, a rural space does not imply a stationary state; instead rural spaces change constantly in relation to the entire uneven social-economic process. In primitive precapitalist societies, there was no (or little) difference between place and space. Their differentiation is the product of history. In the early capitalist mode of production, then-extant semi-autonomous rural (or agrarian) communities were forced to be involved in the process of exchange for goods and services produced in the cities (a spatial practice). Nevertheless, their local identity as 'rural' in a cultural or socio-ecological sense tended to remain the same (a place practice). Unlike manufacturing and service industries, agriculture is a space-based activity, applying labour to a specific place and using extensive physical space for production. Under the current GATT/WTO international trade regime, food production can shift internationally, for example from domestic locations (that have economically inefficient labour intensive agricultural operations) to other locations where intensive capital investment is possible, or where cheap farm labour is available (rural areas in the third world and, to some extent, areas in the United States that employ low-wage migrant labour). In contemporary society, we live in a dualistic spatial environment in which there are always communications, negotiations, and conflicts between a place and a space. In this world, the visible physical landscape of a locality can be understood as a product of the interaction between place, as an expression of local identity, and space, which is the product of a broader regional, national, and global political and economic system.

\section{Rural Tourism}

Tourism is identified as one of the largest economic industries around the world that accounts for $10 \%$ of the global gross domestic product (GDP). Fascinatingly, out of every 10 jobs in the world, one is associated with tourism (World Tourism Organization, 2018). In 2018, the number of international travelers was 1.4 billion people; a business with 1.7 trillion dollars revenue. The significance of this industry is that tourism alone accounts for $7 \%$ of the global total exports, and $29 \%$ of the service exports (World Tourism Organization, 2019). Tourism, is a means of promoting world peace, can be a proper tool to remove the negative image created by Western media about Africa rural scene and opportunity to showcase the rich African culture and biodiversity to the world.

Rural tourism basically focuses on actively participating in a purely rural lifestyle. It can be a variant of ecotourism. Many villages can facilitate tourism because they are hospitable and eager to welcome (and sometime even host) visitors. Improvement in agriculture through mechanized methods that requires less manual 
labour, this trend is has created economic pressure on most villages, which in turn causes young people to move to urban areas. There is however, a segment of the urban population that is interested in visiting the rural areas and understanding their lifestyle, cultural heritage and biodiversity.

Major tourism destinations are mostly in developing countries, include national parks, wilderness areas, mountains, lakes, and cultural sites, most of which are generally rural. Thus tourism is already an important feature of the rural economy in these specific sites. It is self-evident that tourism will never come to dominate all rural areas, particularly in the developing world - there are vast swathes of rural areas for which tourism is not relevant for the foreseeable future. Between these two extremes are poor rural areas with some tourism potential, and an urgent need to develop whatever economic potential they have.

Rural tourism, often called agri- or agro-tourism (Italian: agritourismo; French: tourismevert), is a phenomena particular to and popular policy means of industrialized societies which has find relevance amongst developing countries. Rural tourism could be conveniently be refers to as a kind of self-development initiative that utilizes the unique resources and knowledge peculiarity of a locality to attract urban consumers and tourists. This can be both in practice and ideology to which endogenous rural revitalizing efforts are usually regarded as essential (Okech, Haghiri, \& George, 2012). Rural areas have shown remarkable non-agricultural trends since the 1990s and had gradually experienced a transformation from production spaces to consumption spaces (Marden, 1990). Rural areas are spaces that can be revived through continuous construction and reconstruction (Woods, 2010). In the past 30 years, tourism has become an important driving force for rural rejuvenation and spatial reproduction (Rasoolimanesh, 2016; Wu, et al. 2017). In the intervening period tourism urbanization has taken place in a growing number of villages in developing countries (Mulin, 2010). Many traditional tourism destinations have developed into new service spaces where rural and urban areas are interpenetrated with each other, in so doing indicating new features of tourism urbanization (Li, 2017 \&Vaugeois, 2015). However, the socio-economic structure, resource allocation and the natural landscape element in rural areas have been significantly influenced (Shucksmith, 2016). The ecological environment load has increased and the rural space has become increasingly fragile (Hoggart, \& Paniagua, 2001) due to human activities.

The rural place present the nature of the aspiration, history, experience and understanding of the past through buildings, artifacts, reconstitutions, or other material or immaterial traces and memories such as pilgrimage experience or sharing a sense of spirituality, or sublimation through travel. Roots discovering and experiencing the heritage of one's ancestors' or one's people. Landscape: Seeing and communing with remarkable and beautiful sites, including coastal, mountain, rural, and even man-made landscapes. Shalbafian, Zarandian, \& Rajabi (2020) note that Natural systems, such as ecological and geological discovering of life and appreciating the natural forces that form exceptional places. Such as cultural icons, visiting sites and monuments, including art galleries and museums that is recognized and admired on a national or international basis. In fact, it must be stated that the market trend in tourism has significantly changed. Earlier, quality of the services was a key to distinguish tourism products; whereas, today, visitors look for experiences- they are more often ready to pay higher prices in return for unique experiences. In other words, current visitors are increasingly looking for authenticity, and a way to emotionally engage with the local culture and society which are unique in rural setting (undoubtedly, this is one of the most fundamental and critical trends in the modern tourism around the world); in an extended change, it is rooted in the values and is known as "experience economy" (World Tourism Organization \& European Travel Commission, 2017).

\section{Emerging models for sustainable tourism?}

Sustainable tourism has contributed to renew deeply heritage management guidelines for international organizations and has often been proposed as an alternative to mass tourism. UNESCO emphasizes also the quality value of cultural tourism which would give priority to active transportation, typical local products rather than standardized products without any links to the heritage site (qualified as bad products), local arts and crafts and interpretive centers. Tourism is seen as a source of funding for the sites, contributing to their maintenance and management or as an added value (e.g. farmers living within the site perimeter or in its surroundings). For UNESCO, the site's inhabitants are also heritage protection's ambassadors. The financial benefits are either direct (when the developer is also the site manager) and indirect, when recovered by the private sector (hotels, guesthouses, restaurants, shops...) or the public sector (taxes or various fees...). According to UNESCO, the polluter pays principle should be generalized, although it's impossible sometimes to make visitors pay an entrance fee. In the guidelines, asking fees for pedestrians is still controversial, and the solution of asking payment only for car-parks or motorized access seems to be less conflictual (UNESCO, 2016, http://whc/n2.unesco.org/fr/tourisme/). UNESCO also emphasizes the need to preserve specific areas or places, sometimes with temporary measures. The involvement of local communities (also named host communities) is recalled as essential in all the guidelines presented above. The visitor experience is also highlighted, through "authenticity" and negative impacts are highlighted through folklore.

UNWTO also offers a guide to sustainable tourism in a broader context with models or best practices that 
can be applied to different types of tourist destinations (UNWTO 2004). The contributors guide come from very different countries with a good representation of Canada and Australia (11 from Canada and 10 from the US within the 60 authors -UNWTO 2004).

The guidelines clearly use the UNESCO, ICOMOS and IUCN guidelines for nature protected areas and World Heritage Sites. Even if the guideline is more focused on economic efficiency, it does not exclude the specialized organizations issues.

\section{Conclusion}

As the government is the prime provider of the above mentioned services, then process of imaging Luanda area for rural tourism will depend on the input of government in physical infrastructures. A large proportion of problems experienced by entrepreneurial ventures center around management-related issues, such as inappropriate organizational structure, reluctance to delegate, absence of operational controls and predominance of informal decision-making. For organizations to progress beyond survival requires not only possession of management skills and leadership to include more defined human resource skills, planning and goal setting, financial management and the ability to manage people effectively. Tourism provides many opportunities for small entrepreneurs to contribute to the provision of tourism experiences for financial gain. These opportunities occur in both the formal and informal sectors although, in reality, the distinction between the two may be blurred (Timothy and Wall, 1997).

Most rural areas have been seen as agricultural production and raw materials or extractive mineral base. Not much have been said or done on rural industrialisation or concern for the out migration of educated and noneducated youth. Preserving the rural place through tourism is a viable alternative development strategy with 52.1 percent of rural population below poverty line (NBS, 2019).

If the government's input is well propagated then tourists will come in large numbers to develop the tourism skills in rural areas. This will consequently lead to economic development in rural areas as accruing from tourist's expenditures. Besides, the UNWTO designated year 2020 as the year of Tourism and Rural Development. It is imperative to see it as opportunity to continue the promotion of tourism to create job opportunities. Developing nations can advance inclusion and highlight the unique role tourism can play in preserving and promoting natural and cultural heritage and curbing urban migration. Both urban and rural areas have much in common. Urban areas rely on rural for to meet their requirement for foods, raw materials, etc., which are basically products of rural ecosystem services. It is not gain saying that rural areas also gain from urban development, in terms of market, farm inputs, employment opportunities and so on. Therefore, rural population need policy attention to enable them enhance the ecosystem services they are providing and for the ecosystem to be protected for sustainable service delivery.

Policy on ecosystem services need review for adequate protection for sustainable service delivery that support: a) Promoting poverty eradication in rural areas; b) Promoting pro-poor planning and budgeting at the national and local level; c) Addressing basic needs and enhancing provision for access to services as a precursor to improve livelihood; d) Providing social protection programmes to benefit the vulnerable households. Above all, provide for opportunity for all to have synergies that promote the development of rural organization such as community-driven cooperative to enhance investment in essential infrastructures and services, and recognize the role of urban areas in fostering rural development.

\section{Reference}

Ahn, B.Y.; Lee, B.K.; Shafer, C.S. (2002), "Operationalizing sustainability in regional tourism planning: An application of the limits of acceptable change framework". Tour. Manag., Vol. 23, $1-15$.

Amsden, L.B., Stedman, R.C, \& Kruger, L.E. (2010), "The Creation and Maintenance of Sense of Place in a Tourism-Dependent Community”. Leisure Sciences: An Interdisciplinary Journal, 33:1, - 51.

Ashley, C, \& Roe, D. (2002), "Making Tourism Work for the Poor: Strategies and Challenges in Southern Africa". Development Southern Africa, 19 (1): 61- 82.

Bailoni, M. (2016), "World Heritage in danger and tourism stakes in Europe: global concerns for local planning conflicts. PROCEEDINGS OF TCL2016 CONFERENCE, INFOTA2016; 55-66.

Bailoni, M. (2013), 'Aménager un espace idéalisé : identité et conflits dans la campagne anglaise'. Revue Géographique de l'Est 52(3/4).

Boley, B. B., N. P. Nickerson, \& K. Bosak. (2011), "Measuring Geotourism: Developing and Testing the Geotraveler Tendency Scale (GTS).” Journal of Travel Research, 567- 578.

Brown, K., Turner, R.K., Hameed, H. \& Bateman, I.J. (1997), "Environmental carrying capacity and tourism development in the Maldives and Nepal". Environ. Conserv., Vol. 24, 316-325.

Butler, Richard W. (1990), "Sustainable Tourism: A State-of-the-Art Review." Tourism Geographies, 1 (1): 7 25.

Carter, E.D.; Guzmán, G. \& Silva, B. (2013), “Acculturation, and Environmental Values”: The Case of Mexican 
Immigrants in Central Iowa. Ann. Assoc. Am. Geogr., Vol. 103 129-147.

Cullingworth, B. \& Nadin, V., (2006), “Town and country planning in the UK, 14Th edition". Abingdon: Routledge.

Daly, S. (2015), "Producing healthy outcomes in a rural productive space”. J. Rural Stud., Vol. 40, 21-29.

Dziedzicki, J.-M., (2003), «Au-delà du NIMBY: le conflit d'aménagement, expression de multiples revendications ». In Melé, P., Larrue, C. \& Rosemberg, M. (eds.). Conflits et territoires: 35-4. Tours: Presses Universitaires François Rabelais.

Farrell, B.H.; Twining-Ward, L. (2004), “Reconceptualizing tourism”. Ann. Tour. Res., Vol. 32, $274-295$.

Fennell, David A. (2001). "A Content Analysis of Ecotourism Definitions." Current Issues in Tourism, 4 (5): $403-21$.

Gravari-Barbas, M. \& Veschambre, V., 2003. Patrimoine: derrière l'idée de consensus, les enjeux d'appropriation de l'espace et des conflits. In Melé, P., Larrue, C. \& Rosemberg, M. (eds.). onflits et territoires: 67-82. Tours: Presses Universitaires François Rabelais.

Gunn, C.A. (1998), «Destination zone fallacies and half-truths”. Tour. Manag, Vol. 3, 263-269.

Hall, D.R. (1998), "Tourism development and sustainability issues in Central and South-eastern Europe". Tour. Mana., Vol. 15, 423-43.

Hoggart, K. \& Paniagua, A. (2001), "What rural restructuring. J. Rural Stud.” 2001, 17, 41-62.

Howard, E. (1965), "Garden Cities of Tomorrow"; the MIT Press: Cambridge, MA, USA.

Huang, X.; Bao, J.G.; Wall, G. (2006), “Chinese ecotourism opportunities spectrum” (CECOS). Sci. Geogr., Vol. $26,5629-5634$.

Kiss, E. (2000), "Rural restructuring in Hungary in the period of socio-economic transition". Geo. Journal, Vol. $51,221-233$.

Lefebvre, H. (1992), “The Production of Space”; Wiley -Blackwell: Hoboken, NJ, USA.

Li, L.H. (2017), "Balancing Rural and Urban Development: Applying Coordinated Urban-Rural Development (CURD) Strategy to Achieve Sustainable Urbanization in China”. Sustainability, Vol., 9, 1948.

Li, W.W.; Cao, K. \& Church, R.L. (2016), "Cyber infrastructure, GIS, and spatial optimization: Opportunities and challenges”. Int. J. Geogr. Inf. Sci., Vol.30, 427- 431.

20. Lobley, M. \& Potter, C. (2004), “Agricultural change and restructuring: Recent evidence from a survey of agricultural households in England”. J. Rural Stud. Vol. 20, 499-510.

Marsden, T.; Lowe, P. \& Whatmore, S. (1990), "Rural Restructuring: Global Processes and Their Responses"; David Fulton: London, UK, 1990.

McNamara, D. (2014, July), "Enjoying a Sense of Place." Northwest Earth Institute. http://www.nwei.org/enjoying-sense-place/ Retrieved April 14, 2021.

Moscardo, G., \& Pearce, P.L. (1999), “Understanding Ethnic Tourists.” Annals of Tourism Research, 26 (2): 416 $-34$.

Mullins, P. (2010), “Tourism Urbanization”. Int. J. Urban Reg. Res. Vol. 15, 326-342.

National Bureau of Statistics- NBS (2019), "2019 Poverty and Inequality in Nigeria": Executive Summary (2019) May 2020

National Geographic Center for Sustainable Destinations (2009), “About Geotourism”. http://travel.nationalgeographic.com/travel/sustainable/pdf/about-geotourism.pdf (Retrieved May 10, 2021).

Nelson, P.B. (2001), "Rural restructuring in the American West: Land use, family and class discourses". J. Rural Stud. Vol.17, 395- 407.

Okech, R., Haghiri, M., \& George, B. P. (2012), "Rural Tourism as A Sustainable Development Alternative: An Analysis with Special Reference to Luanda, Kenya. Special Issue: Sustainability, Tourism \& Environment in the Shift of A Millennium": A Peripheral View. Cultur, ano $06-\mathrm{n}^{\circ} 03$

www.uesc.br/revistas/culturaeturismo. Retrieved May,06, 2021.

Prats, M.,\& Thibault, J-P. (2003), 'Qu'est-ce que l'esprit des lieux. In: 14th ICOMOS General Assembly and International Symposium: «Place, memory, meaning: preserving intangible values in monuments and sites" $27-31$ oct. 2003, Victoria Falls, Zimbabwe. [Conference or Workshop Item] Available at: http://openarchive.icomos.org/472/ Retrieved 8 May 2021.

Rasoolimanesh, S.M.; Ringle, C.M.; Jaafar, M.\& Ramayah, T. ( 2016), "Urban vs. rural destinations: Residents' perceptions, community participation and support for tourism development”. Tour. Manag. Vol. 60, 147158.

Rosenow, J. E., \& Gerrald L. P. (1979), "Tourism: the Good, the Bad, and the Ugly." Lincoln, NE: Media Productions \& Marketing.

Scheyvens, R. (2002), “Tourism for Development: Empowering Communities.” Harlow, UK: Prentice Hall.

Shaker, R.R. (2018), "A mega-index for the Americas and its underlying sustainable development correlations". Ecol. Indic Sustainability, Vol.89, 466-479.

Shalbafian, A.A., Zarandian, N., \& Rajabi, N. (2020), "Thematic Tourism; A new Concept for Developing 
Tourism" (Case Study: Rural Areas of Meyami County). Journal of Sustainable Rural Development, 4(1), 89-100. httsp://www.jsrd.ir. Retrieved 03/04/2021.

Sigala, M. (2008), « Managing Tourism Destinations ». Ann. Tour. Res. 35, 836-838.

Shucksmith, M. (2017)," Re-imagining the rural: From rural idyll to Good Countryside”. J. Rural Stud. Vol., 7 , 19.

Stokes, A.M., Cook, S.D., \& Drew, D. (2003), “Geotourism: The New Trend in Travel.” Travel Industry America and National Geographic Traveler.

Subra, P., (2007), « Géopolitique de l'aménagement du territoire ». Paris: A.Colin.

Tao, H., Liu, J.M., Yu, H. \& Zhu, H. (2017), "The conceptual model of the spatial restructuring in the region of tourism urbanization: A case study of Mayangxi Ecotourism Area". Geogr. Res., 36, 1123-1137.

Timothy, D. \& Wall, G. (1997), "Selling to Tourists: s: Indonesian Street Vendor. Annals of Tourism Research", Vol.24, No 2, pp $322-340$.

Tipton, M. E. (2017), "Assessing the Character of Place to Guide Geotourism in Montana: A Case Study of Whitefish and White Sulphur Springs, Montana". Graduate Student Theses, Dissertations, \& Professional Papers. 11035. https://scholarworks.umt.edu/etd/11035 Retrieved May 10, 2021.

Tosun, C. (2006), "Expected nature of community participation in tourism development". Tour. Manag. j.tourma, vol. 27, 493-504.

Tuan, Y.F. (2001), "Space and Place: The Perspective of Experience"; University of Minnesota Press: Minneapolis, MN, USA.

UNESCO, (2016), “Asking fees for pedestrians”. http://whc.unesco.org/fr/tourisme/) Retrieved May, 04/2021.

UNESCO, ICCROM, ICOMOS, UICN (2012), "Gérer le patrimoine mondial naturel,Managing Natural World Heritage”. Paris: UNESCO, 104 p. Available at: http://whc.unesco.org/fr/gerer-le-patrimoine-mondialnaturel. Retrieved May, 052021

UNTWO (2004), "Indicators of sustainable development for tourism destinations". Madrid, Spain: World Tourism Organization.

Vaugeois, N. (2015), "Rural tourism: An international perspective”. Ann. Tour. Res. Vol., 54, 225-226.

Vourc'h, A. (1999), "Premières Rencontres des Grand sites au Domaine du Rayol : "L'esprit des lieux et la gestion des Grands Sites". Ministère de l'aménagement du territoire et de l'environnement, direction de la nature et des paysages, sous direction des sites et paysages, 9 et 10 décembre 1999, $105 \mathrm{p}$.

Wang, R.; Liu, J.M.; Chen, T. \& Tian, D.J. (2010), "Distribution of recreational area in suburban metropolis": A case study of Beijing. Acta. Geogr., Vol. 65, 745-754.

Wang, Z.C. \& Li, J.L. (2006), "Study on the tour industry spatial layout of the Yangtze River delta". Econ. Geogr., vol. 2, 83-86.

Wearing, S. (2001), "Volunteer Tourism: Experiences That Make a Difference." Oxon: CABI International.

WHC, ICOMOS, IUCN, (2013), "Report of the joint reactive monitoring mission" -Alto Douro Wine Region. Paris: UNESCO.

Wolsink, M. (1994), "Entanglement of interests and motives: assumptions behind the NIMBY-theory on facility sitting". Urban Studies 31(6): 851- 866.

Woods, M. (2010), "Rural Taylor and Francis": London, UK.

World Commission on Environment and Development (WCED). (1987),. "Our Common Future". New York: Oxford University Press.

World Economic Forum (2019), “The Travel and Tourism Competitiveness Report”. https://www.weforum.org Retrieved May 03, 2021

World Tourism Organization. (2018), “Tourism Highlights. https://www.eunwto.org

Retrieved May 03, 2021.

World Tourism Organization, \& European Travel Commission. (2017),. "Handbook on Marketing Transnational Tourism Themes and Routes": World Tourism Organization (UNWTO).

Wu, B.H. \& Gao, J. (2017), "Revitalizing traditional villages through rural tourism": A case study of Yuanjia Village, Shaanxi Province, China. Tour. Manag.2017, 63, 223-233. 